\title{
Razkrivanje nepravilnosti v Evropski uniji in Republiki Sloveniji
}

\author{
UDK: 342.5:343:351 \\ Mirko Pečarič \\ Državni svet Republike Slovenije \\ mirko.pecaric@ds-rs.si
}

\begin{abstract}
IZVLEČEK
Vse večji vpliv izvršilne oblasti in njeno poseganje na široka področja družbenega življenja za seboj potegne tudi dogodke, ki so lahko na meji zakonitosti oziroma so nevarni za javno zdravje ali življenje ljudi. Če se je motiti človeško, ta enostavni pregovor ni več enostaven, ko govorimo o nepravilnostih. Vprašanje je $v$ razcepu med pojmovanjem lojalnosti in varovanjem zakonitosti. Za ceno odstopa Evropske komisije v letu 1999 je tudi EU uvedla nekaj postopkov za razkrivanje nepravilnosti, ki se zgledujejo po anglosaksonskem institutu whistleblowinga. Le-ta vse bolj prodira na evropska tla kot ukrep post festum po raznih nesrečah, aferah ali gospodarski nuji prilagajanja tujim podjetjem na svetovnem trgu. Javni sektor zaznamujeta vse višja izobrazbena struktura in strokovnost zaposlenih, kar zahteva tudi temu ustrezno upravljanje s človeškimi viri. Republika Slovenija na tem področju ni izjema, zato se bodo morali temu prilagoditi tudi vodstveni delavci v organih ter predpisi, ki bodo varovali zaposlene pred šikaniranjem. Pregled slovenske zakonodaje in podzakonskih predpisov pokaže, da bo treba razkrivanje nepravilnosti primerneje urediti ter poskrbeti tako za odpravo nepravilnosti kot za zaščito tistega, ki jih je razkril. Meja med delovanjem organa in njegovo zakonitostjo, primernostjo in smotrnostjo zahteva zelo občutljive ukrepe; morda se ravno zato $z$ odpravljanjem nepravilnosti načeloma vsi strinjajo, medtem ko se v praksi zelo malo spremeni.
\end{abstract}

Ključne besede: razkrivanje nepravilnosti, lojalnost, zakonitost, qui tam, Evropski urad za boj proti goljufijam, zaščita zaposlenih, sistem sporočanja nepravilnosti

\section{Uvod}

Področje izvršilne oblasti je bilo v naši, še ne tako pretekli zgodovini, v senci zakonodajne oblasti, predvsem zaradi skupščinskega sistema in drugih značilnosti prostora, ki jih je sistem uporabljal. Veljalo je prepričanje, da je izvršilni del zgolj orodje v rokah skupščine, ki izvršuje njene zahteve, nikakor pa 


\section{Mirko Pečarič \\ Razkrivanje nepravilnosti v Evropski \\ uniji in Republiki Slovenji}

samostojno ne izvaja nobenih nalog s političnim pridihom. Od načina in področja dela izvršilne oblasti je ne/učinkovitost izvajanja političnih odločitev najbolj odvisna. Sprememba družbenega sistema in hitri razvoj z vsemi spremljajočimi oblikami kaže po svetu največje spremembe ravno na področju izvršilne veje oblasti. Le-ta se je za razliko od zakonodajne in sodne oblasti najbolj spremenila in prilagodila zahtevam ljudi in okolja. S porastom vpliva izvršilne oblasti se je v posameznih državah zakonodajna oblast zavedela birokratske moči, zaradi česar se vedno bolj povečuje nadzor nad izvršilno oblastjo. Naše države $\vee$ te tokove še ne moremo uvrstiti, saj vlada skoraj samostojno vodi in upravlja politiko države. Ne obstaja več vprašanje, ali lahko politične institucije nadzirajo birokracijo, pač pa se je pojavilo novo: ali jo lahko nadzirajo, ne da bi ji pri tem škodile. Poudarek na izvršilni oblasti je najbolj prišel do izraza v konstituiranju in delovanju Evropske unije ${ }^{\mathbf{1}}$ (EU) - demokratični deficit, komitologija - ki poskuša kot protiutež s pogodbo o ustavi poudariti klasično načelo demokratičnosti in delitve oblasti.

\section{2. (Ne)razumevanje lojalnosti}

Načelo dobrega upravljanja je povezano s kolektivnim in celostnim sodelovanjem vodstva in zaposlenih ter $\mathrm{z}$ možnostjo svobodnega izražanja mnenja vsakega javnega uslužbenca, ki $\vee$ javnem interesu meni drugače kot vodstvo ali celo vé, da vodstvo nepravilno ali neracionalno ravna. Na vseh področjih, kjer pridejo na plan eksistenčni razlogi, se ob njihovi zadovoljitvi pojavi hvaležnost za storjeno, čustva in lojalnost $v$ prihodnje. Ljudje (in celo živali) instinktivno izhajajo iz tega, da ne grizejo roke, ki jih hrani. $\vee$ organih državne uprave tako vodstvo kot podrejene hrani ista roka - proračun, ne pa konkretni vodja, čeprav izvršuje pravice in dolžnosti predstojnika. Ravno pravilnost izvrševanja in opozarjanje na nepravilnosti boža roko (ki hrani) in obenem varuje tako javni interes kot življenje in zdravje drugih ljudi. Lojalnost ne pomeni brezpogojnega

$1 \mathrm{~V}$ pristojnost EU ne sodi delovanje javnih uprav posameznih članic, vendar lahko EU na področju upravnega sodelovanja, ki sodi v področje podpornih ukrepov, postavlja standarde, na katere naj se pri izgradnji oziroma reformi sistemov javne uprave opirajo države članice. Standardi delovanja so vsebinsko odraz tradicij, ki so se izoblikovale v evropskem upravnem prostoru in smernic, po katerih naj se ravnajo $v$ prihodnje posamezne države. 


\section{Mirko Pečarič \\ Razkrivanje nepravilnosti v Evropski uniji in Republiki Sloveniji}

izpolnjevanja ukazov, pač pa izpolnjevanje obveznosti zaradi dolžnosti, pomeni poštenost in odkritost $v$ ravnanju ${ }^{2}$.

Če lojalnost v okviru družine temelji na zmožnosti življenja, čustev in ljubezni, se $\vee$ delovnem okolju spremeni v zmožnost preživetja, kolegialnosti in partnerstva. Bolj kot je človek odvisen od lojalnosti, večja je potreba po njegovi pravni zaščiti. Če je samoumevno, da so pravično preživljanje, odnosi med partnerjema, starši in otroci, dedovanje, zaščita otrok ipd. pomembnejši od dobrih delovnih odnosov ali same zaposlitve, se v naši družbi lojalnost največkrat pojavlja $\vee$ okviru delovnih odnosov. Kot da je pomembneje biti navidezno prijazen do vodje, kot pa dejansko ustrežljiv do svojih staršev ali otrok ${ }^{\mathbf{3}}$. Vsaka visoka zveneča beseda, ki je $v$ določenih časih zavzela točno določeno vsebino, se sčasoma spremeni $\vee$ dogmo, ki je ni treba več dokazati pač pa le $\vee$ njo preprosto verjeti. Lojalnost, demokracija, trg, družina in druge besede so zgolj besede; ljudem pa morajo nuditi vsebino, ki jo potrebujejo tukaj in sedaj. Ni namreč nujno, da vsaka beseda pomeni enako kot pred več stoletji ali celo desetletji. Ideje vedno nastajajo $v$ sedanjosti (Einstein: obstaja samo sedanjost), oblikujejo se skladno z obstoječo realnostjo, trenutno prakso in institucijami. Delovna lojalnost v okviru normalnih družbenih razmer in pravne varnosti zavzema drugoten pomen, saj ni nujna sestavina preživetja. Kljub temu mora slediti lojalnosti $\vee$ družini tako, da zavzema vsaj majhen del osebne note med tistimi, ki ukazujejo in tistimi, ki izvršujejo. Le tako se tudi pravilo lahko prilagodi vsem dejanskim razmeram. Organizacija mora razviti svoj repertoar odnosov, ki služijo njenemu namenu sodelovanja in kontrole. Ravno ta osebni prostor pa je hkrati prostor konflikta in inovacije, ljubezni in sovraštva. Če je lojalnost pomenila zmožnost preživetja, demokracija volitve, trg prostor za izmenjavo dobrin in družina skupnost ljubezni in mikro gospodarstva, bi lahko danes enake besede imele tudi drugačen pomen. Lojalnost v delovnem okolju ni edini način preživetja, če le-ta ni obojestranska, demokracija niso zgolj volitve, trg že dolgo ne več fizični prostor in družina vse manj gospodarstvo. V osrčju razkritja se nahaja razcep odgovornosti do samega sebe, do javnosti in do svojega delodajalca. Uslužbenec mora načeloma izhajati iz lojalnosti do delodajalca - razen, če prevladajo drugi resni in konkretni razlogi.

2 Ravno tisti uslužbenec je lojalen, ki vodstvu predstavi svoj pogled na določeno zadevo, opozori na možne napake, pohvali dobre zamisli in si prizadeva za njihovo uresničitev. Kdor vedno brezpogojno izpolni ukaz ni lojalen, pač pa le - ubogljiv.

$3 \mathrm{~S}$ tega vidika je toliko bolj nesprejemljivo, da še vedno ni v zadovoljivi meri urejeno tudi področje nasilja v družini. 


\section{Mirko Pečarič \\ Razkrivanje nepravilnosti v Evropski \\ uniji in Republiki Slovenji}

\subsection{Izvori razkrivanja nepravilnosti}

Prvi pogoj za moralno avtoriteto je zmožnost razlikovanja med tem, kar je, in tem, kar ni prav. Dolžnost ravnanja, skladnega z zakonom, ni absolutna zakonska dolžnost je lahko razveljavljena zaradi višjih dolžnosti. Temelje "odgovorne neposlušnosti" lahko najdemo $v$ razkrivanjih nepravilnosti, ki so redka, vendar tako moralno in politično pomembna, da neposlušnost (nepokorščina) zasluži posebno pozornost. Zasluži jo, ker se običajno opraviči glede na zahteve vesti - in prav vest tako visoko vrednotimo, da ji najvišji državni funkcionarji zaprisežejo in želimo (vsaj na načelni ravni), da bi bila eden prevladujočih mejnikov odločanja.

Izraz "razkrivanje nepravilnosti« (whistleblowing) se uporablja za opis dejanj, ki opozarjajo javnost ali vlado na nepravilnosti (še posebno nepravilnosti, ki jih naredi delodajalec), kot so kršitve zakona, nevarnost za varnost in zdravje ostalih javnih uslužbencev, in kršitve dobro sprejetih standardov profesionalne etike. Whistleblowing, to je piskanje na piščal, prihaja iz prakse angleških policistov, ki so s piskanjem opozarjali javnost in druge policiste na nevarnost ali hudodelstva ${ }^{\mathbf{4}}$. Razkrivanje nepravilnosti predstavlja pravico do nekaznovane, tj. zaščitene, neškodljive in učinkovite svobode izražanja. Izraz se uporablja za primere, ko uslužbenec medijem, tistim, ki sprejemajo odločitve, ali drugim avtoritetam razkrije informacije o nezakonitem ali neprimernem ravnanju nekega organa. Razkrivanje se včasih razlikuje od svobode govora $v$ tem, da zaposleni uporabijo informacije, ki so dostopne njim kot uslužbencem; izjave o neprimernosti se tako nanašajo bolj na aktivnosti organa kot na širše javno področje.

Čeprav se je razkrivanje $v$ taki ali drugačni obliki pojavljalo skozi vso zgodovino, so svetovno znan primer prav dramatični dogodki, ki so privedli do grožnje z impeachmentom in do odstopa predsednika Richarda Nixona (afera Watergate op.). Primer je vrgel na površje zadeve, ki se nanašajo na informacije, pridobljene od zaposlenih. Leta 1978 je s Civil Service Reform Act predsednik Jimmy Carter reagiral na zlorabo Nixona z vključitvijo določil o zaščiti pravice zaposlenih, ki razkrijejo informacije glede neprimernega ravnanja vladnih organov in uradnikov (Dresang, 1999: 52).

4 Whistleblower protection, http://www.workrights.org/issue-whistle/wb-legislativebrief.html 


\section{Mirko Pečarič \\ Razkrivanje nepravilnosti v Evropski uniji in Republiki Sloveniji}

Razkrivanje nepravilnosti izhaja iz antične Grčije (atenska ustava 350 let pr.n.št.) in srednjeveške Anglije iz 13. stoletja, kjer se je razvilo v smislu pomoči posameznikov pri uresničevanju državnih ciljev. Iz Anglije se je preneslo tudi v ZDA, kjer je tudi danes še vedno najbolj razširjeno. Kot odpor proti goljufijam $\vee$ zvezi s preskrbo vojske ( $\vee$ zaboje so dobavitelji dajali pesek namesto mušket, domnevno zdrave mule so bile bolne, slepe ali večkratno precenjene ipd.) si je Lincolnova administracija leta 1863 v False Claims Actu pomagala z institutom qui tam, ki izhaja iz srednjeveške Anglije. Akcija qui tam je okrajšava iz latinščine "qui tam pro domino rege quam pro sic ipso in hoc parte sequitur" in pomeni "tisti, ki toži v kraljevem in svojem imenu." Gre za tožbo, vloženo na podlagi zakona, ki omogoča posamezniku, da zahteva odškodnino, katere del bo prejela tudi vlada ali druga javna institucija. Pogosto se krajša kot qui tam (Q.T.); znana je tudi kot popularna tožba. Tožbe qui tam so služile kot pravno sredstvo zasebnih državljanov za pridobitev dostopa do kraljevih sodišč. V srednjem veku Anglija namreč ni imela organizirane policije, ki bi skrbela za izvrševanje zakonov ${ }^{\mathbf{5}}$. Iz primera ZDA in Velike Britanije vidimo, da se je institut uveljavljal več stoletij, da bi šele v sedanjem času lahko polno zaživel. V ZDA je kongres marca letos sprejel nov (četrti po vrsti) predlog zakona o povečani zaščiti razkrivalcev nepravilnosti (Whistleblower Protection Enhancement Act), ki izvira iz samega nastanka ZDA in goljufij v secesijski vojni; Velika Britanija je šele 1998 leta sprejela Zakon o razkrivanju nepravilnosti $v$ javnem interesu (Public Interest Disclosure Act), čeprav naj bi se prvi "napad" na uradno tajnost zgodil že leta $1844^{6}$. Vzrok za sprejem zakona so bili škandali in nesreče $v$ zgodnjih devetdesetih letih prejšnjega stoletja. Skoraj vsaka preiskava je ugotovila,

5 Bryan A. Garner, Black's Law Dictionary, 8th ed., Thomson West 2004, str. 1282. Dostopno tudi na: http://www.quitam.com, www.falseclaimsact.com/history.html False Claims Act je bil dopolnjen leta 1986, ko je vsa povračila uredil bolj generalno. V okviru tega zakona razkrivalec vloži tožbo qui tam v imenu vlade, Ministrstvo za pravosodje pa v postopek lahko intervenira, če to želi. Če se vlada pridruži tožbi, lahko razkrivalec dobi do $25 \%$ vrednosti razsodbe, če je primer uspešen; če se vlada ne pridruži, lahko razkrivalec obdrži do $30 \%$ vrednosti sodbe. Nagrade te vrste so bile prav tako vključene $v$ druge zvezne zakone, kot so Financial Institutions Reform in Recovery and Enforcement Act.

6 Pomladi leta 1844 je Joseph Mazzini, italijanski izgnanec $v$ Londonu, začel dajati v pisma makova zrnca in drobce peska. Ugotoviti je namreč hotel, ali mu britanska vlada pregleduje korespondenco po nalogu avstrijskega ambasadorja. Ko so se ovojnice vrnile prazne, se je dogovoril s poslancem Thomasom Duncombom, da je $v$ predstavniškem domu vložil protest glede načina vohunjenja tujih držav, ki je "nasproten vsem načelom britanske ustavnosti in uničevalen do javnega zaupanja, ki je tako pomembno za trgovsko državo". Zavrnitev ministra za notranje zadeve J. Grahama, da bi potrdil ali ovrgel Duncombove navedbe, pomeni prvi sodoben napad na uradno tajnost (Vincent 1999: 1). Celoten pregled britanske tajnosti za zadnjih 166 let je dostopen v delu Davida Vincenta: The Culture of Secrecy: Britain 1832-1998, University Press: Oxford 1999. 


\section{Mirko Pečarič \\ Razkrivanje nepravilnosti v Evropski \\ uniji in Republiki Slovenji}

da so se zaposleni zavedali nevarnosti, vendar so bili preveč prestrašeni, da bi o tem poročali ${ }^{\mathbf{7}}$ ali so opozorili na njo na napačen način ali napačni osebi ${ }^{\mathbf{8}}$.

\section{Evropska unija}

EU kot institucija novejšega izvora nima dolge zgodovine razkrivanja nepravilnosti, je pa kmalu reagirala tudi na ta pojav. Decembra 1998 je namreč Paul van Buitenen, revizor v Direktoratu za finančno kontrolo Evropske komisije $\checkmark$ Bruslju, spregovoril o veliki korupciji in goljufijah $v$ samem srcu Komisije. Navkljub hudim pritiskom, da bi molčal, je razkril resnični nivo korupcije Evropskemu parlamentu - rezultat je bil odstop Santerjeve Komisije marca 1999 z Jacquesom Santerjem na čelu in odstop evropske komisarke Edith Cresson. Razkritje nepravilnosti je plačal tako, da so ga odstavili z delovnega mesta ${ }^{\boldsymbol{9}}$.

\subsection{Kodeks dobrega obnašanja za javne uslužbence}

Septembra 2001 je Evropski parlament sprejel resolucijo, s katero je odobril Kodeks dobrega obnašanja za javne uslužbence (Code of Good Administrative Behaviour), katerega naj bi spoštovale institucije in organi EU, njihove administracije in uslužbenci v povezavi z delom, ki ga opravljajo. Kodeks se opira na Listino o temeljnih pravicah EU (2000/C 364/01), ki je v 41. členu določila pravico do dobrega upravljanja. Kodeks dobrega obnašanja za javne uslužbence

7 Primeri so se nanašali na železniško nesrečo $v$ južnem Londonu (the Clapham Rail crash 35 mrtvih) - v Hiddnovi preiskavi je bilo ugotovljeno, da je inšpektor videl zrahljane žične vode, vendar ni rekel nič, ker ni hotel poslabšati stvari); eksplozija na ploščadi Piper Alfa (the Piper Alpha disaster - 167 mrtvih) - Cullenova preiskava je zaključila, da zaposleni niso hoteli ogroziti svoje zaposlitve za nedoločen čas zaradi pomanjkljive varnosti, ker niso hoteli osramotiti vodstva"); propad banke BCCl (Bank of Credit and Commerce International - $\$ 20$ bilijonska izguba) - Binghamova preiskava je odkrila avtokratsko vodstvo zaradi katerega se ni nihče upal spregovoriti.

8 Nesreča trajekta pri pristanišču Zeebrugge (Sheenova preiskava je ugotovila, da je osebje petkrat javilo vodstvu, da trajekti plujejo z odprtimi vrati); propad Barings banke (eden izmed višjih vodij ni opozoril na nepravilnosti jasno in odločno); preiskava "Orožje za Irak" (Scottovo poročilo je ugotovilo, da je zaposleni pisal na ministrstvo za zunanje zadeve in jih opozoril na proizvodnjo orožja, ki je bilo namenjeno za Irak). Podobna sporočila izhajajo iz preiskav o zlorabi otrok $v$ varstvu (prek 30 prijav je bilo ignoriranih glede serijske spolne zlorabe, ki jih je storil Frank Beck) in preiskave glede malomarnega zdravljenja; ena zadnjih je bila Kennedyjeva preiskava glede visoke smrtnosti otrok pri operacijah srca v Bristolski kraljevi bolnišnici. Dostopno na: http://www.pcaw.co.uk/policy_pub/pida.html

9 Svoja doživetja je opisal v knjigi Blowing the Whistle: Fraud in the European Commission, Politicos Pub, 2000. 


\section{Mirko Pečarič \\ Razkrivanje nepravilnosti v Evropski uniji in Republiki Sloveniji}

je torej zgolj konkretnejša izpeljava temeljne pravice do dobrega upravljanja. Po pravici do dobrega upravljanja ima vsak pravico, da institucije in organi EU njegove zadeve obravnavajo nepristransko, pravično in $v$ razumnem roku. $V$ povezavi s 43. členom, ki govori o varuhu človekovih pravic, je dobro upravljanje lahko včasih žal zagotovljeno šele na tej ravni, tj. ko bi ga morda lahko uporabili javni uslužbenci EU (javni uslužbenci bi lahko podali pritožbo samo po 43. členu, ne pa tudi po 41. členu, saj se pravica do dobrega upravljanja, nanaša zgolj na zadeve, kjer so državljani stranke $v$ postopku), ko njihova priporočila ne bi dosegla plodna tla v okviru okolja, kjer so zaposleni.

Vsak državljan EU in vsaka fizična ali pravna oseba s prebivališčem ali statutarnim sedežem $\vee$ eni od držav članic ima pravico, da se glede nepravilnosti pri delovanju institucij in organov EU obrne na varuha človekovih pravic EU, razen glede sodišča in sodišča prve stopnje $\vee$ njuni pravosodni funkciji. Kodeks zavezuje javne uslužbence med drugim tudi k zakonitosti, nediskriminaciji, sorazmernosti ${ }^{\mathbf{1 0}}$, izogibanju zlorabe oblasti, nepristranskosti in neodvisnosti, objektivnosti, legitimnim pričakovanjem"1, konstistentnosti in pomoči strankam, poštenosti, ter vljudnosti. Vse to so seveda hkrati tudi razlogi, zaradi katerih se lahko državljani pritožijo varuhu.

\subsection{Kadrovski predpisi za uradnike Evropskih skupnosti in pogoji za zaposlitev drugih uslužbencev Evropskih skupnosti}

Uredba Sveta EU (ES, Euratom) št. 723/2004 z dne 22. marca 2004, je spremenila Kadrovske predpise za uradnike EU in pogoje za zaposlitev drugih

10 Pri sprejemanju odločitev mora javni uslužbenec zagotoviti, da so sprejeti ukrepi sorazmerni zasledovanemu cilju. Javni uslužbenec se mora še posebej izogibati omejevanju pravic državljanov ali dodajanju obremenitev, če te omejitve ali obremenitve niso $v$ razumnem razmerju z zasledovanim ciljem. Pri sprejemanju odločitev mora javni uslužbenec spoštovati pravično razmerje med zasebnim interesom strank in javnim interesom. Določba je veliko bližja dejanskemu življenju, kot zgolj pooblastilo zakonodajalcu (če ni izrecno predpisano), da lahko uporablja test sorazmernosti zgolj pri sprejemanju zakonodaje ne pa javnim uslužbencem pri njenem izvajanju.

11 Legitimno pričakovanje je za naše obravnavanje zanimivo $v$ toliko, ker določa, da mora javni uslužbenec spoštovati običajne administrativne prakse organa, razen če obstaja zakonita podlaga za odstop od teh praks $v$ posamičnem primeru. Ta podlaga mora biti pisno zabeležena. 


\section{Mirko Pečarič \\ Razkrivanje nepravilnosti v Evropski \\ uniji in Republiki Slovenji}

uslužbencev EU ${ }^{\mathbf{1 2}}$. Svet EU je ob upoštevanju Pogodbe o ustanovitvi EU, zlasti člena 283 Pogodbe, sprejel tudi omenjeno uredbo, ki je začela veljati 1. maja 2004. Uredba je $\vee$ celoti zavezujoča in se neposredno uporablja $\vee v s e h$ državah članicah. Vodilo potrebnih sprememb je razbrati predvsem iz uvodnega dela uredbe:

"Od leta 1962, ko so bili sprejeti prvi Kadrovski predpisi in pogoji za zaposlitev, je prišlo do velikega družbenega napredka in novosti. Ta napredek in novosti se morajo odražati $v$ ureditvenem okviru, ki se uporablja za evropsko javno upravo, s čimer se zadovoljijo spreminjajoče se potrebe institucij in $\vee$ njih zaposlenih in pri tem spoštujeta upravna kultura in tradicija EU, ki temeljita na načelu služenja državljanom. EU mora zato imeti visoko kakovostno javno upravo, ki zagotavlja najvišji standard opravljanja njenih nalog v skladu s Pogodbami in doraslost notranjim in zunanjim izzivom, s katerimi se bo soočila $v$ prihodnosti. Širši cilj je zagotoviti čim učinkovitejše upravljanje človeških virov v evropskih javni upravi, za katero so značilne usposobljenost, neodvisnost, lojalnost, nepristranskost in stalnost pa tudi kulturna in jezikovna različnost. Nedvoumna je potreba po krepitvi načela kariernega razvoja na podlagi odlik in vzpostavitvi tesnejše povezave med delovno uspešnostjo in osebnimi prejemki, tako da se s strukturnimi spremembami kariernega sistema predvidi višje spodbude za večjo delovno uspešnost, pri tem pa zagotovi enakovrednost povprečnih kariernih profilov $v$ novih in starih strukturah ter upoštevata kadrovski načrt in proračunska disciplina. Posodabljanje kariernega sistema zahteva, da se $v$ večji meri priznavajo uradnikove poklicne izkušnje in načelo vseživljenjskega učenja. Zato je zaželeno, da se sedanje kategorije nadomestijo in zaposleni razvrstijo $v$ nove funkcionalne skupine, in sicer upravljavci (AD) in strokovni sodelavci (AST) ter da se olajša napredovanje iz nižje $v$ višjo skupino s pomočjo novega postopka ocenjevanja. Ker je pravica do svobode izražanja vsebovana $v$ Listini o temeljnih človekovih pravicah, je treba uradnikom zagotoviti to temeljno pravico in določiti razumne meje njenega uresničevanja. Zagotoviti je treba nov pravni okvir in jamstva za pravno varstvo uradnikov, ki jasno definiranim osebam ali organom naznanijo možno nezakonito dejavnost ali obnašanje, ki pomeni hudo kršenje obveznosti uradnikov v službi EU«.

12 Kadrovski predpisi za uradnike EU in Pogoji za zaposlitev drugih uslužbencev EU, določeni v Uredbi (EGS, Euratom, ESPJ) št. 259/68, nazadnje spremenjeni z Uredbo (ES, Euratom) št. 2182/2003. 


\section{Mirko Pečarič \\ Razkrivanje nepravilnosti v Evropski uniji in Republiki Sloveniji}

V členu 17a je določeno, da ima uradnik pravico do svobode izražanja, pri čemer mora spoštovati načela lojalnosti in nepristranskosti. Brez poseganja $v$ člena 12 in 17 mora uradnik, ki namerava sam ali skupaj z drugimi objaviti ali sprožiti objavo katere koli zadeve $v$ zvezi z delom EU, o tem predhodno obvestiti organ za imenovanja. Kadar organ za imenovanja lahko dokaže, da bi ta zadeva verjetno resno škodila legitimnim interesom EU, uradnika $v$ tridesetih delovnih dneh po prejemu informacije pisno obvesti o svoji odločitvi. Če $v$ določenem roku obvestila o taki odločitvi ni, se šteje, da organ za imenovanja razkritju ne ugovarja.

Po členu 21a uradnik, ki dobi navodila, za katera meni, da so nepravilna ali bi lahko povzročila resne težave, o tem obvesti neposredno nadrejenega, ki mu, če je obvestilo $v$ pisni obliki, odgovori pisno. Če neposredno nadrejeni potrdi navodila, uradnik pa je prepričan, da ta potrditev ni razumen odgovor na njegov pomislek, pisno vprašanje predloži naslednjemu nadrejenemu. Če slednji pisno potrdi navodila, jih uradnik izvaja, razen če so očitno nezakoniti ali pomenijo kršitev ustreznih varnostnih standardov. Če neposredno nadrejeni meni, da je treba navodila izvršiti takoj, jih uradnik izvaja, razen če so očitno nezakonita ali pomenijo kršitev ustreznih varnostnih standardov. Na uradnikovo zahtevo mora neposredno nadrejeni dati taka navodila $\vee$ pisni obliki.

Uradnik, ki pri opravljanju nalog ali v povezavi z njimi izve za dejstva, na podlagi katerih je mogoča domneva o obstoju nezakonite dejavnosti, vključno z goljufijo ali korupcijo, ki škodi interesom EU, ali o ravnanju $v$ zvezi z opravljanjem poklicnih nalog, ki lahko pomeni hudo kršenje obveznosti uradnikov EU, po 22a členu o tem nemudoma obvesti svojega neposredno nadrejenega ali svoj generalni direktorat ali, če sem mu zdi to koristno, generalnega sekretarja ali osebe na enakovrednih položajih ali neposredno Evropski urad za boj proti goljufijam (OLAF). Informacije morajo biti dane pisno. Vsak uradnik, ki dobi take informacije, nemudoma posreduje OLAF-u vse dokaze, za katere ve in na podlagi katerih je mogoče sklepati na obstoj nepravilnosti. Zaradi posredovanja informacij iz tega člena uradnik ne utrpi nobenih škodljivih posledic, pod pogojem, da je ravnal razumno in pošteno. Omenjeno določilo ne velja za dokumente, listine, poročila, obvestila ali podatke v kakršni koli obliki, ki se hranijo za sodne postopke ali pripravijo ali razkrijejo uradniku med sodnimi postopki, ki so $v$ teku ali so že končani.

Po členu 22b uradnik, ki razkrije informacije, opredeljene $v$ členu 22a, predsedniku Komisije ali Računskega sodišča ali Sveta ali Evropskega parla- 


\section{Mirko Pečarič \\ Razkrivanje nepravilnosti v Evropski uniji in Republiki Slovenji}

menta ali evropskemu varuhu človekovih pravic, od institucije, ki ji pripada, ne utrpi nobenih škodljivih posledic, pod pogojem, da sta izpolnjena oba spodaj navedena pogoja:

a) uradnik je pošteno in utemeljeno prepričan, da so razkrite informacije in vse navedbe resnične; in

b) uradnik je iste informacije predhodno razkril OLAF-u ali svoji instituciji in se je strinjal z rokom, ki ga je OLAF ali institucija, glede na zapletenost zadeve, določila za sprejetje ustreznega ukrepa. O tem roku $^{\mathbf{1 3}}$ se uradnika obvesti v šestdesetih dneh.

\subsection{Evropski urad za boj proti goljufijam (OLAF) ${ }^{14}$}

Proračun skupnosti prav tako kot pri državah članicah financirajo davkoplačevalci. Evropska politika, ki je financirana na tak način, je namenjena realizaciji projektov $v$ splošnem interesu, zato vsa ravnanja, ki so namenjena izogibanju plačevanja davkov ali dajejo nepravilne rezultate pri danih sredstvih, povzročajo škodo evropskemu davkoplačevalcu. Evropske institucije morajo zagotoviti, da je denar kar najbolje uporabljen, in se boriti proti zlorabam vsakršne vrste, kar je v zadnjem času ena pomembnejših prioritet. Za krepitev boja proti goljufijam, korupciji in drugim nezakonitim dejanjem, ki vplivajo na finančne interese EU, je bil tako ustanovljen Evropski urad za boj proti goljufijam, s sklepom Komisije št. 1999/352/ES, ECPJ, Euratom (v nadaljevanju "OLAF"), ki izvaja pooblastila preiskovanja, prenesena na Komisijo s pravili, predpisi in sporazumi EU, ki veljajo na teh področjih. Osnova za delovanje urada sta 274. (ex 205) ${ }^{\mathbf{1 5}}$ člen in 280. (ex 209a) ${ }^{\mathbf{1 6}}$ člen Pogodbe o Evropski uniji.

13 Rok se ne uporabi, kadar uradnik lahko dokaže, da je glede na vse okoliščine zadeve nerazumen.

$14 \mathrm{http}: / /$ europa.eu.int/comm/anti_fraud/

15 Komisija izvršuje proračun v skladu z določbami uredb, sprejetih na podlagi člena 209, na lastno odgovornost in $v$ mejah odobrenih proračunskih sredstev, pri čemer upošteva načela dobrega finančnega poslovodenja. Uredbe za vsako institucijo določajo podrobna pravila, ki se nanašajo na njen delež odhodkov. Ob upoštevanju omejitev in pogojev, ki jih določajo uredbe, sprejete $v$ skladu s členom 279, lahko Komisija $v$ okviru proračuna odobrena sredstva prerazporedi med področji porabe ali med njihovimi sestavnimi deli.

16 EU in države članice preprečujejo goljufije in vsa druga nezakonita dejanja, ki škodijo finančnim interesom EU, z ukrepi, sprejetimi v skladu s tem členom, ki delujejo svarilno in so takšni, da v državah članicah omogočajo učinkovito zaščito. Države članice sprejmejo za preprečevanje goljufij, ki škodijo finančnim interesom EU, enake ukrepe, kakršne sprejmejo za preprečevanje goljufij, ki škodijo njihovim lastnim finančnim interesom. Brez poseganja $v$ 


\section{Mirko Pečarič \\ Razkrivanje nepravilnosti v Evropski uniji in Republiki Sloveniji}

OLAF je bil torej ustanovljen predvsem zaradi učinkovite uvedbe načela dobrega finančnega poslovodenja. Sem sodi prosto razporejanje sredstev med proračunskimi postavkami, kar opravlja Komisija, ter preprečevanje goljufij in vseh drugih nezakonitih dejanj, ki škodijo finančnim interesom EU. Postopek delovanja OLAF-a je predpisan v Uredbi (ES) št. 1073/1999 Evropskega parlamenta in sveta $z$ dne 25. maja 1999 o preiskavah, ki jih izvaja OLAF. Po 3. členu uredbe $v$ institucijah, organih, uradih in agencijah, ustanovljenih s Pogodbami ali na podlagi teh pogodb ( $v$ nadaljevanju "institucije, organi, uradi in agencije"), OLAF izvaja upravne preiskave za boj proti prevaram, korupciji in drugim nezakonitim dejanjem, ki vplivajo na finančne interese EU. Preiskuje tudi resne zadeve $\vee$ zvezi z izvajanjem službenih dolžnosti, ki pomenijo zanemarjanje delovnih nalog uradnikov in drugih uslužbencev EU, ki bi lahko imeli za posledico disciplinski oziroma kazenski postopek, ali enako neizpolnjevanje obveznosti članov institucij ali organov, vodij uradov in agencij ali uslužbencev institucij, organov, uradov ali agencij, za katere ne veljajo Kadrovski predpisi za uradnike in pogoji za zaposlovanje drugih uslužbencev EU ("Kadrovski predpisi").

OLAF ima v okviru preiskav pravico do neposrednega in nenapovedanega dostopa do vseh podatkov, s katerimi razpolagajo institucije, organi, uradi in agencije in do njihovih prostorov. OLAF ima pooblastilo za pregled poslovnih knjig institucij, organov, uradov in agencij. OLAF lahko zahteva ustno izjavo članov institucij in organov, vodstva uradov in agencij ter uslužbencev institucij, organov, uradov in agencij. Če se pri preiskavah pokaže morebitna osebna vpletenost člana, vodstva, uradnika ali drugega uslužbenca, morajo biti o tem obveščeni institucija, organ, urad ali agencija, ki ji/mu pripada. Kjer je zaradi preiskave potrebna popolna zaupnost ali uporaba preiskovalnih sredstev, ki spadajo $\vee$ pristojnost nacionalne sodne oblasti, se lahko razkritje takšnih podatkov začasno odloži (člen 4 Uredbe).

\footnotetext{
druge določbe te pogodbe države članice usklajujejo svoje delovanje, katerega cilj je zaščita finančnih interesov EU pred goljufijami. $V$ ta namen skupaj s Komisijo organizirajo tesno in redno sodelovanje med pristojnimi organi. Svet sprejme $v$ skladu s postopkom iz člena 251 in po posvetovanju z Računskim sodiščem potrebne ukrepe za preprečevanje in boj proti goljufijam, ki škodijo finančnim interesom EU, da bi omogočil učinkovito in enakovredno zaščito $v$ državah članicah. Ti ukrepi ne zadevajo uporabe nacionalnega kazenskega prava ali pravosodja $v$ državah članicah. Komisija $v$ sodelovanju z državami članicami vsako leto predloži Evropskemu parlamentu in Svetu poročilo o ukrepih, ki so bili sprejeti zaradi izvajanja tega člena.
} 


\section{Mirko Pečarič \\ Razkrivanje nepravilnosti v Evropski \\ uniji in Republiki Slovenji}

V 7. členu Uredbe je določena dolžnost obveščanja OLAF-a. Institucije, organi, uradi in agencije morajo OLAF-u takoj pošiljati vse podatke $v$ zvezi $z$ morebitnimi primeri goljufije ali korupcije ali drugih nezakonitih dejanj ter če to dopušča nacionalna zakonodaja, države članice na zahtevo OLAF-a ali na svojo pobudo pošljejo OLAF-u vse dokumente ali podatke $v$ zvezi z notranjo preiskavo $\vee$ teku, s katerimi razpolagajo, in vse druge koristne dokumente ali podatke, s katerimi razpolagajo in ki se nanašajo na boj proti goljufijam, korupciji in vsem drugim nezakonitim dejanjem, ki vplivajo na finančne interese EU.

Po zaključku preiskave, ki jo izvede OLAF, le-ta pod vodstvom direktorja po 9. členu pripravi poročilo, $v$ katerem navede ugotovljena dejstva, morebitno finančno izgubo in ugotovitve preiskave vključno s priporočili direktorja urada o ukrepih, ki jih je treba sprejeti. Pri pripravi takšnih poročil se morajo upoštevati postopkovne zahteve, določene $v$ nacionalni zakonodaji posamezne države članice. Tako pripravljena poročila so dopustni dokazi $\vee$ upravnih ali sodnih postopkih države članice, $v$ katerih se njihova uporaba izkaže za potrebno, na isti način in pod istimi pogoji kakor upravna poročila, ki jih pripravijo nacionalni upravni inšpektorji. Za ta poročila veljajo ista pravila ocenjevanja, kakor veljajo za upravna poročila, ki jih pripravijo nacionalni upravni inšpektorji, in so tem poročilom enakovredna. Poročila, pripravljena po opravljeni notranji preiskavi, in vsi koristni dokumenti v zvezi s preiskavo se pošljejo zadevni instituciji, organu, uradu ali agenciji. Institucija, organ, urad ali agencija na podlagi notranje preiskave sproži ustrezne postopke, predvsem disciplinske ali sodne, kakor zahtevajo rezultati teh preiskav, in o tem poroča direktorju urada $v$ roku, ki ga ta določi v ugotovitvah na koncu poročila.

OLAF ima tudi nadzorni odbor, ki krepi neodvisnost OLAF-a z rednim nadzorom in spremljanjem izvajanja preiskovalne funkcije. Na zahtevo direktorja ali na svojo pobudo odbor izdaja direktorju mnenja o delu OLAF-a, vendar se na noben način ne vmešava $v$ izvajanje preiskav $v$ teku. Odbor sestavlja pet neodvisnih zunanjih oseb s kvalifikacijami, ki se $v$ njihovih državah zahtevajo za imenovanje na vodilna delovna mesta $\vee$ zvezi $s$ področjem dela urada. Soglasno jih imenujejo Evropski parlament, Svet in Komisija.

Da delo uslužbencev OLAF-a ne bi bilo nedotakljivo, je 14. člen določil nadzor zakonitosti. Do spremembe Kadrovskih predpisov lahko po tem členu vsak uradnik ali drugi uslužbenec EU pri direktorju OLAF-a vloži pritožbo proti škodljivemu dejanju zoper njega, ki ga stori OLAF med izvajanjem notranje preiskave, v skladu s postopki iz člena 90(2) Kadrovskih predpisov. Za odločbe, 


\section{Mirko Pečarič \\ Razkrivanje nepravilnosti v Evropski uniji in Republiki Sloveniji}

sprejete $\vee$ zvezi s takšnimi pritožbami, se uporablja člen 91 Kadrovskih predpisov. Zgornje določbe se po analogiji uporabljajo tudi za uslužbence institucij, organov, uradov in agencij, za katere Kadrovski predpisi ne veljajo. $\vee$ tretjem letu po začetku veljavnosti te uredbe Komisija pošlje Evropskemu parlamentu in Svetu poročilo o delu OLAF-a, priloži pa mu mnenje nadzornega odbora in po potrebi predloge za spremembo ali razširitev nalog OLAF-a".

Primerjava med varuhom človekovih pravic in OLAF-om kaže, da se varuh ukvarja z vsemi primeri slabe administracije, kjer pride do kršenja temeljnih pravic državljanov od institucij in organov EU, medtem, ko se OLAF bori proti prevaram, korupciji in drugim nezakonitim dejanjem, ki vplivajo na finančne interese EU. Preiskuje tudi resne zadeve v zvezi z izvajanjem službenih dolžnosti, ki pomenijo zanemarjanje delovnih nalog uradnikov in drugih uslužbencev EU, ki bi lahko imeli za posledico disciplinski oziroma kazenski postopek. Poročila OLAF-a so dopustni dokazi v upravnih ali sodnih postopkih države članice, v katerih se njihova uporaba izkaže za potrebno, na isti način in pod istimi pogoji kakor upravna poročila, ki jih pripravijo nacionalni upravni inšpektorji, medtem ko to ne velja za varuhove izsledke. Varuh si glede na ugotovljeno dejansko stanje prizadeva najti prijazno rešitev in da organu, ki je $\vee$ postopku, priporočila za ravnanje ali svojo odločitev. Če je organ ne upošteva, varuh pošlje poročilo Evropskemu parlamentu, za razliko od OLAF-a, katerega priporočila mora organ oziroma institucija upoštevati. Varuh človekovih pravic glede na določila tudi ne more preiskovati pritožb zoper državne, pokrajinske in lokalne organe oblasti, tudi če se te nanašajo na zadeve EU, medtem ko OLAF lahko preiskuje tudi države članice, kjer obstaja sum, da je prišlo do nepravilnega ravnanja z denarjem EU tj. ravnanja, ki je $v$ nasprotju s finančnimi interesi EU. Tako Evropski varuh človekovih pravic in OLAF $\vee$ grobem povzemata vsebino ameriškega postopka whistleblow, ki ga pozna tudi Velika Britanija kot članica EU.

17 Iz poročila o delu OLAF-a (http://europa.eu.int/comm/anti_fraud/reports/olaf/20022003/en.pdf) za obdobje od 1.7.2002 do 30.6.2003 izhaja, da so prejeli 563 novih zadev (od tega 3 iz Slovenije) in odprli 375 preiskav. Do konca tega obdobja je bilo skupaj evidentiranih 3440 zadev in zaključenih 805 preiskav s skupno vrednostjo več kot 850 milijonov (iz Kosova je bilo $v$ tem obdobju nazaj uspešno pridobljenih 2,7 milijona). Zoper Slovenijo se vodi 8 preiskav. Nove zadeve $v$ tem obdobju sestavlja 40 zadev s področja cigaret, alkohola in davka na dodano vrednot, 64 zadev s področja carine, 95 zadev s področja kmetijstva, 100 zadev $\mathrm{s}$ področja strukturnih skladov, 123 zadev s področja zunanjih pomoči, 79 zadev s področja neposredne porabe in 62 zadev z anti-korupcijskega področja. 


\section{Mirko Pečarič \\ Razkrivanje nepravilnosti v Evropski uniji in Republiki Slovenji}

\section{Razkrivanje nepravilnosti v OECD}

Slovenija je del antikorupcijske mreže OECD, dne 16. 5. 2007 je država prejela povabilo za razpravo glede sprejema $\vee \mathrm{OECD}$, zato se lahko glede nepravilnosti ozremo tudi na omenjeno organizacijo. Le-ta je pripravila osnutek pripomočkov za razreševanje interesnih konfliktov $v$ javnem sektorju (Draft OECD toolkit for managing conflict of interest in the public sector ${ }^{\mathbf{1 8}}$, ki je bil pripravljen 5. in 6. maja 2004 v Rio de Janeiru. Osnutek je namenjen kot vodilo za sprejem podobnih ukrepov in je eden izmed kazalnikov, da tudi OECD razmišlja o uvedbi sistema razkrivanja nepravilnosti, ki jih storijo organi javne uprave in njeni uslužbenci. Poseben poudarek je dan tranzicijskim državam, kamor po mnenju OECD sodi tudi naša država. Pripomočki za razreševanje interesnih konfliktov $v$ javnem sektorju so namenjeni zagotovitvi vira praktičnih idej in instrumentov za politike in vodje za razvoj, sprejem in primerno uporabo $\checkmark$ njihovih lastnih političnih in administrativnih kontekstih. Zaščita razkrivanja nepravilnosti $\vee$ javnem interesu je ključen korak pri boju zoper korupcijo ${ }^{\mathbf{1 9}}$ in nepravilnosti, ki jih storijo uradniki: če se razkritja nepravilnosti ne identificira, je tudi malo verjetno, da bo nadzorovano. Zato je pomembno, da so razkritja bona fide, ki so storjena skladno s pravili, tudi učinkovito zaščitena. Pomembno je zagotoviti, da razkrivalec ne more kontrolirati postopka preiskave ali njenega rezultata: pomembno se je osredotočiti na razkritje samo in na vprašanje ali je resnično. Prav tako pomembno za javno zaupanje $v$ javne institucije je, da javni uslužbenci na vseh ravneh spoštujejo razkritja, ki morajo nato biti primerno obravnavana. Medtem, ko se je $v$ preteklosti na zakone o razkrivanju nepravilnosti

$18 \mathrm{http} / / /$ www.oecd.org/dataoecd/3/45/31571360.pdf

19 R Slovenijo na področju korupcije zavezuje Zakon o ratifikaciji Civilnopravne konvencije o korupciji (MCKK), ki ga je sprejel Državni zbor Republike Slovenije na seji 27. marca 2003 in je objavljen $v$ Uradnem listu, MP, št. 8/2003. Deveti člen določa zaščito zaposlenih in nalaga vsaki pogodbenici, da $v$ svojem notranjem pravu zagotovi ustrezno zaščito pred vsakim neupravičenim kaznovanjem zaposlenih, ki imajo razloge za sum korupcije in ki v dobri veri sporočijo svoj sum pristojnim osebam ali organom. V R Sloveniji pa dejansko ni predvidenih niti organov, kamor bi lahko sporočali take podatke, kaj šele postopek. Bil je sprejet Zakon o preprečevanju korupcije (Ur.I. RS, št. ) in na njegovi podlagi Poslovnik komisije za preprečevanje korupcije (Ur.I. RS, št. 105/2004), ki pa $v$ nobenem členu ne določata, da bi lahko uslužbenci javljali sume korupcije, kaj šele, da bi predvideli postopek. Kljub temu 14. člen poslovnika določa, da v kolikor komisija ugotovi, da obstajajo razlogi za sum kaznivega dejanja ali drugih kršitev, za katere komisija ni pristojna, le-ta sprejme sklep o odstopu zadeve pristojnemu organu. Obvezni deli sklepa so: osnovni podatki o možnem kršitelju, utemeljitev razlogov za sum, podatki o pristojnem organu in rok, $v$ katerem mora pristojni organ komisiji poročati o svojih ugotovitvah. Nikjer se nihče ni vprašal, kje bo komisija prišla do kakovostnih informacij, na podlagi katerih bi lahko zahtevala posredovanje podatkov o sumu koruptivne dejavnosti. 


\section{Mirko Pečarič \\ Razkrivanje nepravilnosti v Evropski uniji in Republiki Sloveniji}

gledalo z nekakšnim zaničevanjem, se lahko sodobni uporabni primeri najdejo v ZDA, Veliki Britaniji, Avstraliji in Novi Zelandiji. Zakon o razkrivanju nepravilnosti naj bi zagotavljal način, kako naj bi lahko ljudje javljali nepravilnosti v javnem sektorju razkrivanje v javnem interesu. Osnutek je pripravil tudi izhodišča za pripravo takšnega zakona in organigram poteka takšnega postopka (glej organigram na str. 56).

\section{Vpliv ameriške zakonodaje o razkrivanju nepra- vilnosti na evropski prostor}

Ameriški Sarbanes-Oxley Act (SOX) iz leta 2002 (sprejet po propadu dveh največjih ameriških podjetij, Enron in WorldCom) v četrtem odstavku 304. člena določa, da mora imeti vsako podjetje, ki kotira z delnicami na ameriškem trgu, $\vee$ okviru svoje revizijske komisije predvidene "postopke za sprejem, hrambo in obravnavo pritožb, ki jih je prejel izdajatelj glede računovodstva, notranjih računovodskih kontrol ali revizijskih zadev; in zaupno, anonimno predložitev pritožb zaposlenih pri izdajatelju glede spornega računovodstva ali revizorskih zadev". SOX ščiti $\vee$ 806. členu vsakega zaposlenega, ki razkrije informacije (razkritje zajema poleg same informacije o nepravilnostih tudi pričanje ali kakršnokoli pomoč pri raziskavi nepravilnosti) članom kongresa ali njegovim komisijam, zveznemu uradniku, podjetniškim nadzorniku, državnemu ali lokalnemu uradniku, medijem ali drugim članom javnosti. Zaposleni mora utemeljeno misliti, da razkrita nepravilnost pomeni kakršnokoli kršitev zveznih zakonov, ki se nanašajo na goljufije nasproti lastnikom, goljufije varnostnih in borznih pravil (ta pravila vzpostavljajo pravico lastnika, da vé za dejavnosti, ki povzročajo materialna tveganja ali so povzročila materialni vpliv na vrednost delnice podjetja).

Zakon zagotavlja, da delniška družba, ki javno trguje, katerikoli uradnik, zaposleni, pogodbeni partner, podizvajalec ali zastopnik podjetja, ne sme odpustiti, degradirati, suspendirati, groziti, nadlegovati ali kakorkoli drugače diskriminirati zaposlenega $\vee$ zvezi s pogoji njegove zaposlitve. Za nadzor nad izvajanjem SOX-a je zadolžena komisija za nadzor trgovanja z vrednostnimi papirji (Securities and Exchange Commission), določila pa so nadalje vključena $\checkmark$ pravila Newyorške borze NYSE in elektronske borze Nasdaq. Če podjetje kotira na eni izmed omenjenih borz, mora letno potrditi svoje računovodske izkaze, vključno s pravili za prijavo nepravilnosti. $V$ nasprotnem primeru se družbe soočijo s težkimi sankcijami in kaznimi SEC-a, NYSE-ja ali Nasdaqa. 
Mirko Pečarič

\section{Razkrivanje nepravilnosti v Evropski \\ uniji in Republiki Slovenji}

\section{Kaj se zgodi, ko opravite razkritje v javnem interesu?}

Prvi korak - stopite $v$ stik z organom javne uprave glede informacij s tega področja. Odločite se ali boste opravili razkritje (podali informacije o nepravilnostih). Stopite v kontakt s pristojnim organom.

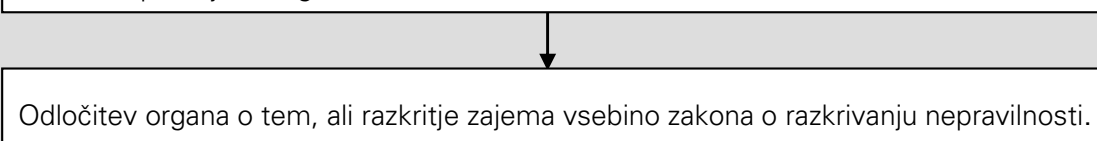

Če je vsebina razkritja v okviru predmetnega zakona bo organ:

- uvedel preiskavo;

- stopil v kontakt z drugim organom z namenom

skupne preiskave;

- posredoval razkritje drugemu organu ali ombudsmanu.

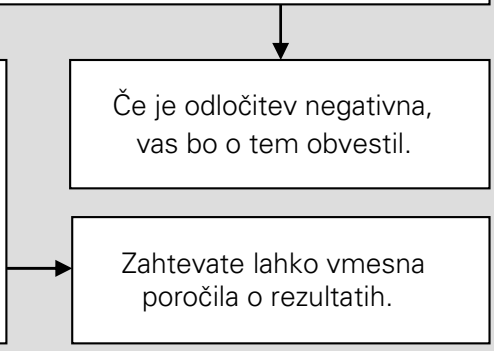

Neodvisna preiskava bo ugotovila navedbe, vsebovane v razkritju. Glede na naravo primera, lahko preiskava vključuje zbiranje informacij od neposredno udeleženih oseb. Če izsledki kažejo, da se je zgodilo kaznivo dejanje, se lahko preiskava usmeri na preprečitev nadaljnje škode.

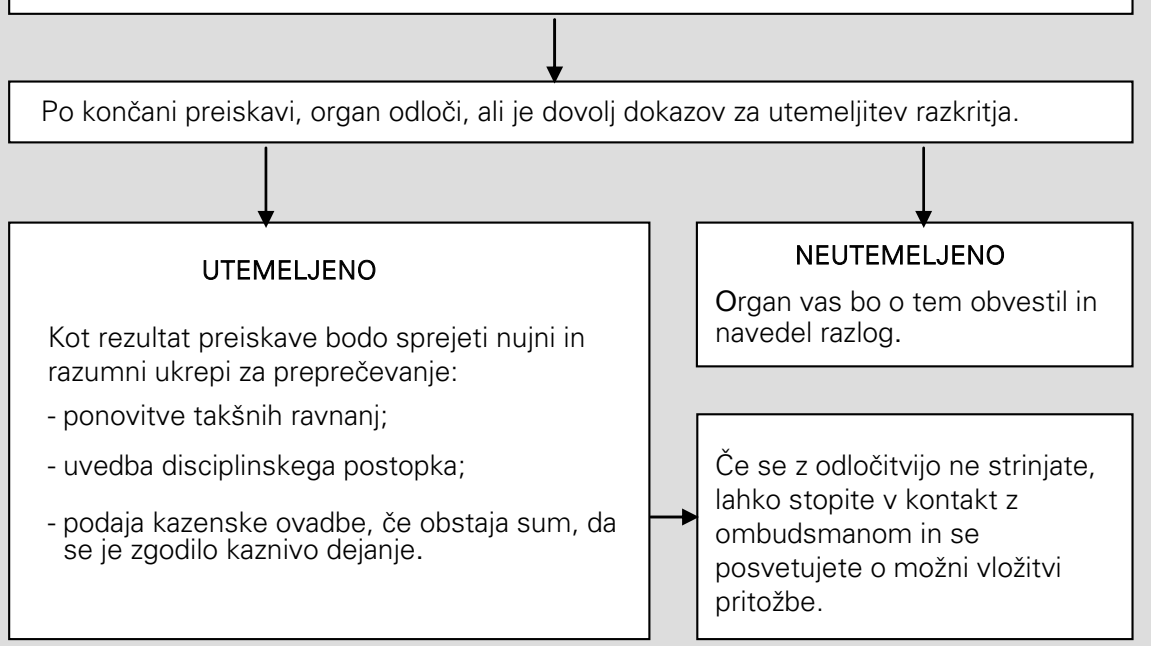

V katerikoli fazi, se lahko organ odloči, da ne bo več ukrepal glede razkritja če: se že drug organ javne uprave ali sodišče ukvarjata s to zadevo; organ meni, da razkritje nima osnove; ali če obstaja primernejše sredstvo za ureditev zadeve. 


\section{Mirko Pečarič \\ Razkrivanje nepravilnosti v Evropski uniji in Republiki Sloveniji}

Zahtevo po sistemu sporočanja nepravilnosti (whistleblower scheme) morajo izpolnjevati tudi evropska podjetja $v$ ZDA, ki kotirajo na ameriškem trgu vrednostnih papirjev in morajo zaradi svojega sedeža poslovati tudi $v$ skladu z Direktivo 95/46/ES Evropskega parlamenta in Sveta o varstvu posameznikov pri obdelavi osebnih podatkov in o prostem pretoku takih podatkov (direktiva); obratno velja tudi za ameriška podjetja, ki opravljajo svojo dejavnost v Evropi, zato morajo poleg zahtev iz SOX-a izpolnjevati tudi zahteve iz direktive. Delovna skupina za varstvo podatkov (ustanovljena v skladu s členom 29 Direktive 95/46/ES) je zato 1. februarja 2006 sprejela mnenje o uporabnosti pravil EU o varstvu osebnih podatkov $v$ zvezi z notranjimi shemami razkrivanja nepravilnosti s področja računovodstva, notranjih računovodskih kontrol, revizijskih zadev, boja proti podkupovanju, bančnemu in finančnemu kriminalu ${ }^{20}$.

Razkrivanje nepravilnosti je zasnovano kot dodaten mehanizem zaposlenih za sporočanje nepravilnosti po posebnih, za to predvidenih poteh. Uporablja se kot dodatek $k$ rednim informacijskim potem in sistemom poročanja znotraj podjetja, kot so sindikalni zaupniki, linijsko vodstvo, osebe za nadzor kakovosti ali notranji revizorji, ki so zaposleni prav zaradi sporočanja ugotovljenih nepravilnosti. Na razkrivanje naj se gleda kot na subsidiarno sredstvo in ne kot na nadomestek za notranji menedžment. Delovna skupina ugotavlja, da so pravila o razkrivanju nepravilnosti zasnovana z namenom zaščite razkrivalca nepravilnosti, medtem ko zanemarjajo zaščito obtožene osebe, zato morajo te osebe kljub obtožbi uživati varstvo iz Direktive 95/46ES.

Sistemi sporočanja nepravilnosti so $\vee$ Evropi vzbudili skrb najprej $\vee$ Franciji $^{\mathbf{2 1}}$, kjer je Državna komisija za informacije in svoboščine (Commission nationale de l'informatique et des libertés - CNIL) v primeru francoskih podružnic

20 Opinion 1/2006 on the application of EU data protection rules to internal whistleblowing schemes in the fields of accounting, internal accounting controls, auditing matters, fight against bribery, banking and financial crime. Dostopno na: http://ec.europa.eu/justice_home/ fsj/privacy/docs/wpdocs/2006/wp117_en.pdf. Skupina je bila mnenja, da bi bilo prezgodaj sprejemati dokončno mnenje o razkrivanju nepravilnosti na splošno, zato se njeno mnenje nanaša le na zgoraj omenjena področja, tj. področja, za katera je mnenje nujno potrebno.

21 Koncept anonimnosti se je $v$ Franciji dotaknil boleče rane in spominov na drugo svetovno vojno, ko so sosedje anonimno ovajali sosede Vichyjevemu režimu. Le-ta je zaprl okoli 135.000 ljudi, interniral naslednjih 70.000, izgnal okoli 76.000 Judov in poslal 650.000 francoskih delavcev na delo $v$ Nemčijo. Francozov je strah predvsem tega, da bi lahko anonimni sistem sporočanja nepravilnosti privedel do organiziranega sistema profesionalnega ovajanja. Koncept anonimnega sistema sporočanja nepravilnosti je v EU naletel na prepreke, ki temeljijo na kulturnih normah in možni nekompatibilnosti s predpisi EU glede varovanja osebnih podatkov. 


\section{Mirko Pečarič \\ Razkrivanje nepravilnosti v Evropski uniji in Republiki Slovenji}

ameriških podjetij McDonnalds in CEAC (Exide Technologies) odločila, da ne izpolnjujeta zahtev francoske zakonodaje o varovanju osebnih podatkov. Medtem ko po ameriškem mnenju anonimnost stimulira sporočanje neprimernih aktivnosti, je po francoskem anonimnost povabilo k zlorabam (Bender, 2006). CNIL je zaradi tega 10. novembra 2005 izdal navodila za uvedbo sistema sporočanja nepravilnosti $v$ skladu $s$ francoskim zakonom o varovanju podatkov $^{\mathbf{2 2}}$. CNIL ugotavlja ${ }^{\mathbf{2 3}}$, da takšni sistemi niso niti dovoljeni niti prepovedani. Na splošno komisija nima zadržkov do takšnih sistemov, če zagotavljajo zaščito pravic inkriminiranih oseb, skladno s pravili o varstvu osebnih podatkov in $\mathrm{s}$ podanimi smernicami (subsidiarna narava, omejen obseg, neobvezna uporaba; omejene kategorije vključenih oseb $v$ sistem; restriktivna obdelava anonimnih sporočil; jasna in obsežna informacija o sistemu potencialnim uporabnikom; zbiranje sporočil prek za to določenih sredstev; relevantni, ustrezni in nepretirani podatki $\vee$ prijavah; obdelava internih prijav, rezervirana za specialiste $\vee$ zaupnem okolju; krožeča statistična poročila o stanju, ki ne razkrivajo identitete prijaviteljev; omejen čas zadrževanja informacij; točna informacija inkriminirani osebi in podrejanje pravici do dostopa in popravka). Osmega decembra 2005 je CNIL izdal dokument "autorisation unique" glede obdelave osebnih podatkov $v$ okviru sistemov sporočanja nepravilnosti. $V$ njem podaja osnovne pogoje za avtomatsko odobritev sistemov sporočanja $v$ družbah, ki izpolnjujejo zahteve iz dokumenta (večinoma gre za enake zahteve kot v navodilih).

Če družba izpolnjuje vse zahteve, o tem zgolj obvesti CNIL, če pa v čem odstopa, poda zahtevo za avtorizacijo, ki jo CNIL vodi kot konkreten postopek ${ }^{\mathbf{2 4}}$.

Večina držav članic EU bi verjetno odobravala sistem sporočanja nepravilnosti, če bi izpolnjevala zahteve Direktive 95/46/ES Evropskega parlamenta in Sveta o varstvu posameznikov pri obdelavi osebnih podatkov. Tako SOX kot Direktiva zasledujeta za države članice EU zakoniti interes, ki je $v$ varstvu načel dobrega upravljanja in pravic posameznika. Prijave se lahko nanašajo na kršitve s področja računovodstva, notranjega računovodskega nadzora, revizijskih zadev, boja proti podkupovanju, bančnemu in finančnemu kriminalu. Velika

22 Glede na datum nastanka lahko ugotovimo, da so bile francoske smernice izdane pred mnenjem Delovne skupine za varstvo podatkov $v$ okviru EU, ki je svoje mnenje skoraj v celoti prilagodila francoskemu.

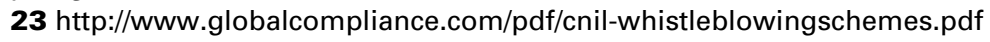

$24 \mathrm{Npr}$. če se nepravilnosti nanašajo izven finančnega, računovodskega in bančnega področja ali boja proti korupciji in zadevajo vitalne interese družbe - npr. konflikt interesov, diskriminacija, nadlegovanje, javno zdravje...). Dostopno na: http://www.cnil.fr 


\section{Mirko Pečarič \\ Razkrivanje nepravilnosti v Evropski uniji in Republiki Sloveniji}

Britanija določa tudi razlog, ki je $v$ javnem interesu; če ga uskladimo $s$ 7(f) členom omenjene Direktive, je obdelava možna zaradi zakonitega interesa, za katerega si prizadeva država, razen kadar prevladajo temeljne pravice in svoboščine posameznika, na katerega se osebni podatki nanašajo.

\section{Republika Slovenija}

Pravno varstvo in arbitražno reševanje sporov je $\vee$ Zakonu o javnih uslužbencih (Ur.I. RS, št. 56/2002 - ZJU) določeno v 24. členu, ki govori o tem, da se o pravici oziroma obveznosti javnega uslužbenca, razen navodil za delo $v$ okviru opisa nalog delovnega mesta, oziroma o zahtevi za odpravo kršitev pravice iz delovnega razmerja, odloči s pisnim sklepom, ki mora biti obrazložen in vročen javnemu uslužbencu. Če javni uslužbenec meni, da delodajalec ne izpolnjuje obveznosti iz delovnega razmerja ali krši katero od njegovih pravic iz delovnega razmerja, ima pravico zahtevati, da delodajalec kršitev odpravi oziroma da svoje obveznosti izpolni. Zoper odločitev o pravici oziroma obveznosti iz delovnega razmerja javnega uslužbenca in zoper kršitev pravic iz delovnega razmerja je dovoljena pritožba, če zakon ne določa drugače. Pritožba zadrži izvršitev odločitve o pravici oziroma obveznosti iz delovnega razmerja javnega uslužbenca, če zakon ne določa drugače. Zoper sklep o pravici oziroma obveznosti iz delovnega razmerja je dovoljeno sodno varstvo pred delovnim sodiščem pod pogojem, da je javni uslužbenec izkoristil možnost pritožbe.

ZJU govori v svojih določbah le o pravicah in obveznostih iz delovnega razmerja, medtem ko o navodilih za izvrševanje del iz opisa nalog delovnega mesta molči. Načelo odprtosti do javnosti v 32. členu določa, da organ obvešča javnost o svojem delovanju in rezultatih opravljenega dela, pri tem pa pozabi na obveščenost uradnikov, ki jo ima za samoumevno. Člen 35 govori o komisiji za pritožbe iz delovnega razmerja zoper (zopet samo) odločitve o pravicah ali obveznostih iz delovnega razmerja javnega uslužbenca, zoper kršitve pravic iz delovnega razmerja in o drugih vprašanjih, kadar zakon tako določa. Iz tega izhaja, da pravice in obveznosti iz delovnega razmerja zajemajo zgolj pravice in obveznosti iz delovnega razmerja $\vee$ ožjem pomenu tj. glede samega izvajanja dela in iz njega izvirajočih delovnopravnih pravic; določene so s predpisi s področja delovnega prava in kolektivnih pogodb, ne pa glede pravic javnih uslužbencev do aktivnega sodelovanja pri izvrševanju zakonov, podzakonskih 


\section{Mirko Pečarič \\ Razkrivanje nepravilnosti v Evropski uniji in Republiki Slovenji}

predpisov ali odkrivanju nepravilnosti. Smotrna in edino uresničljiva načela zakonitosti, strokovnosti, odgovornosti za rezultate, dobrega gospodarjenja in varovanja poklicnih interesov, bi bila možna šele pod pogojem zaupanja pravic javnim uslužbencem do sodelovanja; zgolj grožnja z uvedbo disciplinskega postopka v primeru kršitve ne more biti motivirajoči faktor dobrega upravljanja.

Javni uslužbenec je kazensko, odškodninsko in disciplinsko odgovoren, če pri opravljanju dela po navodilih in odredbah po 94. členu ZJU ni zahteval pisne zahteve, oziroma če je izpolnil nejasno ali protipravno navodilo ali odredbo. Javni uslužbenec lahko tako zahteva pisno odredbo in pisno navodilo ${ }^{\mathbf{2 5}}$ če meni, da je vsebina ustne odredbe ali ustnega navodila nejasna ali če meni, da bi izvršitev ustne odredbe oziroma navodila pomenila protipravno ravnanje oziroma povzročila škodo. Lahko pa odkloni izvršitev odredbe oziroma navodila, če bi pomenila protipravno ravnanje, česar ne more storiti zaradi vzroka povzročitve škode; mora pa odkloniti izvršitev odredbe oziroma navodila, če bi pomenila kaznivo dejanje. Izogib odškodninski in disciplinski odgovornosti poteka zgolj med uslužbencem in njegovim nadrejenim, medtem ko sam postopek ni predviden, tako glede same zahteve po izdaji pisnega navodila, njegove oblike, o nadaljnjih možnostih podrejenega zoper nadrejenega, ki je zahteval izvršitev protipravnega dejanja in (ne)možnosti upoštevanja zahtev po izdaji pisne odredbe nadrejenega pri določitvi ocene, ki jo zopet po 114. členu določi nadrejeni.

Zavzemam se za uvedbo postopka, kjer bi lahko uslužbenci predhodno ali naknadno (kjer to zaradi nujnih ali operativnih vidikov ne bi bilo možno že pred izvršitvijo) predlagali preveritev navodila oziroma odredbe nadrejenega. $V$ postopku bi kot organ odločanja lahko ustanovili neke vrste začasen ali stalen organ, ki bi ga sestavljali ugledni uradniki določenega organa ali drugi strokovnjaki, ki bi nezavezujoče podali svoje mnenje; če uslužbenec z njim ne bi bil zadovoljen, mu ostane sodna pot. Kot eno izmed možnosti bi bila sprva predvidena uvedba pogajanj, soočanje mnenj med uslužbencem in nadrejenim ter drugim vodstvom, v primeru neuskladitve pa tudi uvedba kasnejše "poravnalne komisije « strokovnjakov. Tako bi z uvedbo komisij (uradniškega sveta?) omogočili neko vrsto mediacije, poravnave, ki bi lahko preprečila kasnejše sodne poti in zaradi "hitrosti« odločanja preprečila številne nepotrebne škode. Nastajala bi neka vrsta nezavezujoče strokovne prakse, ki bi preverjala pravilnost odločitev

25 Člen 138: če je javni uslužbenec oproščen odškodninske odgovornosti po šestem odstavku 94. člena tega zakona, je odškodninsko odgovoren nadrejeni, ki je izdal odredbo oziroma navodilo. 


\section{Mirko Pečarič \\ Razkrivanje nepravilnosti v Evropski uniji in Republiki Sloveniji}

ob morebitnih tožbah organa, ki bi odločal o pravici ali obveznosti strank, samim uslužbencem pa bi dajala pomemben občutek vplivanja na prakso izvajanja zakonov in podzakonskih aktov. Narava delovnopravnega razmerja med nadrejenim in podrejenim je vezana na nekatere eksistenčne pravice podrejenih (zaposlitev, plača, pravice iz socialne varnosti), zato ni mogoče enostavno trditi, da imajo na voljo vse veljavne sodne poti, ki jih na njihovem delovnem mestu ne bi kakorkoli prikrajšale ali obvarovale pred šikaniranjem vodstva, ki ga lahko zavije pod številne druge razloge (verjetno je najpogostejša premestitev brez soglasja zaradi potreb organa, najskrajnejša pa izredna odpoved delovnega razmerja). Podrejenemu mora biti omogočeno, da sporoči domnevno nepravilnost, ne da bi bil zaradi tega kakorkoli kaznovan. Kako lahko podrejeni npr. ovadi nadrejenega za zlorabo položaja ali napeljevanje (ki je kaznivo, tudi če dejanje ni bilo niti poskušeno za KD, za katera se sme po zakonu izreči tri leta zapora ali več) oziroma stranko, če se nadrejeni z ovadbo ne strinja, ne da bi pri tem utrpel kakršnekoli posledice?

Kodeks ravnanja javnih uslužbencev (Ur.I. RS, št. 8/2001) je sprejela Vlada RS in naložila ministrstvom in vladnim službam, da kodeks upoštevajo $v$ postopkih zaposlovanja in pri pripravi zakonskih in podzakonskih aktov s področja organizacije in delovnopravne zakonodaje; prav tako se je zavezala, da bo kodeks smiselno uporabljala tudi za ministre in druge funkcionarje. Zakon o javnih uslužbencih je predpisal v prvem odstavku 93. člena, da mora javni uslužbenec opravljati delo v skladu s predpisi, kolektivno pogodbo, pogodbo o zaposlitvi, splošnimi akti organa in kodeksom etike. Kodeks ni usklajen z določbami zakona, saj je bil sprejet pred ZJU, na neresnost pa kaže tudi dejstvo, da je Vlada RS zgolj dobesedno prevedla priporočilo kodeksa, katerega je kot priporočilo sprejel Svet Evrope. Kodeks je v 12. členu določil prijavo nezakonitega ravnanja ${ }^{\mathbf{2 6}}$. Pravila nezakonitega ravnanja se sklicujejo na skladnost

26 Javni uslužbenec, ki meni, da se od njega zahteva ravnanje, ki je nezakonito, nepravilno ali neetično in pri katerem gre za delovanje, ki ni v skladu s tem kodeksom, mora to prijaviti v skladu z zakonom. Javni uslužbenec mora $v$ skladu z zakonom prijaviti pristojnemu organu, če ugotovi, da drugi javni uslužbenci kršijo ta kodeks. Javni uslužbenec, ki je kar koli od navedenega prijavil v skladu z zakonom in meni, da odziv ni sorazmeren z njegovo skrbjo, lahko zadevo pisno prijavi predstojniku ustreznega organa. Če zadeve ni mogoče rešiti s postopki in pritožbami, določenimi $v$ predpisih o javni upravi, tako da bo to sprejemljivo za javnega uslužbenca, mora javni uslužbenec izpeljati navodila, ki mu jih da predstojnik. Javni uslužbenec mora pristojnim organom prijaviti vsak dokaz, navedbo ali sum nezakonitega ali kaznivega dejanja v zvezi z opravljanjem javnih nalog, za katere je izvedel med zaposlitvijo ali v zvezi z njo. Preiskavo o prijavljenih dejstvih opravijo pristojni organi. Zagotoviti se mora, da je javni uslužbenec, ki je kar koli od navedenega prijavil iz utemeljenega razloga in v dobri veri, varovan pred šikaniranjem, grožnjami in podobnim ravnanjem, ki ogroža opravljanje javnih nalog. 


\section{Mirko Pečarič \\ Razkrivanje nepravilnosti v Evropski uniji in Republiki Slovenji}

ureditve z zakonom, na pristojne organe, ki naj bi obstajali pod taktirko predstojnika ustreznega organa, na zadeve, ki naj bi se rešile s postopki in pritožbami, določenimi v predpisih o javni upravi, vendar moramo ugotoviti, da ZJU, ki naj bi urejal te postopke javnih uslužbencev, o tem molči; nasprotno, celo zahteva, da mora uslužbenec opraviti delo, čeprav bo s tem storil škodo ali disciplinsko kršitev. V 94. členu ZJU je sicer določeno, da javni uslužbenec lahko odkloni izvršitev odredbe, če bi le-ta pomenila protipravno dejanje ali kaznivo dejanje, vendar za ugotovitev protipravnosti ali možnosti storitve kaznivega dejanja ne predpisuje nobenega "preliminarnega postopka " glede na to, da so za ugotavljanje odgovornosti zaradi storitve prekrška ali kaznivega dejanja za to določeni drugi pristojni organi. Prav tako ne predpisuje nobenih organov, kamor bi se lahko prijave podajale. Tako ugotavlja tudi Matjaž Albreht v člankih » Javni uslužbenci brez učinkovite zaščite" in "Vlada si zatiska oči in ušesa» (Delo, 19.4.2004 in 10.7.2004) $)^{\mathbf{2 7}}$. Tudi če gornje ugotovitve pustimo ob strani, moramo ugotoviti, da morajo biti pravica in razlogi za njo urejeni z zakonom, zato kodeks per se ni učinkovit način reševanja in odpravljanja domnevnih nepravilnosti. Nedavni in še vedno trajajoči primer davčnega inšpektorja dr. Djordja Perića, ki ga je doletela izredna odpoved delovnega razmerja, je pokazal vso moč oblasti, $v$ imenu katere posamezniki posežejo po najhujših in najskrajnejših sredstvih za dosego svojih ciljev, ne da bi se vprašali o drugih pravnih možnostih. Ugovarjanje v imenu strokovnosti je pravica in dolžnost vsakega javnega uslužbenca, ki ga zagotavlja načelo strokovnosti iz 9. člena ZJU. Načelo v nadaljevanju zakona ni

27 Navaja, da je Urad za preprečevanje korupcije na podlagi Kodeksa $v$ dobrih dveh letih prejel 64 prijav. $\vee$ zgolj dvanajstih primerih so bili prijavitelji znani, $v$ sedmih pa so kršitve prijavile javne institucije na podlagi nadzornih pregledov. Urad ugotavlja, da anonimne prijave kažejo, da se prijavitelji bojijo maščevanja, šikaniranja ali groženj delodajalcev, sodelavcev ali predstojnikov. Bojazni so bile $v$ nekaterih primerih, ko je urad predal prijave pristojnemu organu, upravičene. $V$ nekaterih primerih anonimnih prijav so pristojni začeli odkrivati prijavitelje - namesto da bi preverili resničnost prijav in odpravili vzroke in posledice ugotovljenih nepravilnosti. $V$ odsotnosti domnevnih prijaviteljev so celo pregledovali delovne prostore. Delodajalci so prijavitelja zaradi "krivdnih razlogov" tudi premestili na drugo delovno mesto ali so mu odpovedali delovno razmerje. Javni uslužbenec lahko $v$ takšnem primeru uveljavlja svoje pravice le $v$ okviru rednih pravnih postopkov, ki pa zaradi dolgotrajnosti ne pomenijo učinkovitega varstva javnih uslužbencev. $Z$ določbami kodeksa ravnanja javnih uslužbencev se je ukvarjal tudi odbor za notranjo politiko državnega zbora. Ugotovil je, da zaščita prijaviteljev po pravni poti ni ustrezna; zaščiteni bi morali biti takoj ob prijavi nezakonitega ravnanja. Zato so predlagali uradu, naj za zaščito prijaviteljev nezakonitih ravnanj spodbudi ustrezno sodelovanje med pristojnimi ministrstvi in drugimi državnimi organi, vlada pa naj zagotovi takojšnje učinkovite ukrepe za zaščito prijaviteljev, saj tudi neučinkovito varstvo omogoča nastanek korupcije. V Sloveniji torej ta hip ni institucije, ki bi lahko učinkovito zaščitila javne uslužbence, kadar ti v skladu s kodeksom, v dobri veri prijavijo nepravilnosti pristojnemu organu. 


\section{Mirko Pečarič \\ Razkrivanje nepravilnosti v Evropski uniji in Republiki Sloveniji}

izpeljano, zato se ga navadno uporablja le enosmerno - organi in njihovi vodje radi poudarjajo, da so njihovi javni uslužbenci strokovnjaki, ko pa ti povedo nazaj kaj strokovnega, kar ni povšeči vodstvu, ne gre več za strokovnjaka, pač pa za diletanta in zlorabo uradnega položaja. Na področje razkrivanja nepravilnosti se navezuje tudi človekova pravica svobode izražanja (39. člen URS) in v njunem okviru posebno vprašanje, ali je javnim uslužbencem dovoljena javna kritika dela državnih organov. ZJU tega ne prepoveduje, nekateri pa se zavzemajo za to, da bi "morala svoboda mnenja na tem področju ostati neokrnjena oz. da morajo biti njene meje enake kot v vseh drugih primerih" (Virant, 2004: 116). Slovenska sodna praksa ne beleži primera, ko bi uradnik kritiziral delo vlade, medtem ko se sodna praksa Evropskega sodišča za človekove pravice osredotoča predvsem na ločevanje uslužbenskih mest, v okviru katerih se opravljajo naloge javne oblasti (imperium) in na druge, kjer delo ni povezano z izvrševanjem javne oblasti (ne glede na formalno delo $\vee$ okviru javne uprave) ${ }^{\mathbf{2 8}}$. Uvedba detektivov $\vee$ ZJU za zlorabo potnih stroškov ali bolniške odsotnosti, predlog zakona o detektivski dejavnosti pa tudi njihova uporaba za poizvedovanje $v$ vseh disciplinskih kršitvah, ukinitev komisije za preprečevanje korupcije kot neodvisnega organa in "neproblematični" konflikti interesov so primeri, ki dopuščajo zmanjševanje strokovnosti, častnega ravnanja, svobode izražanja javnih uslužbencev in ugleda državnih organov. Če upoštevamo, da imajo vsi ljudje približno enako domišljijo, jo imajo tisti z možnostjo uporabe proračunskih sredstev in "uradnih" pooblastil na voljo še nekoliko več. V takih okoliščinah je iluzorno pričakovati, da bi kdo sam od sebe kaj povedal o javnih razpisih (in njihovih ozadjih), o gradnji Pediatrične ali Nevrološke klinike, operacijskih mizah, opremi in drugih zadevah, ki trenutno pestijo slovensko politiko.

\section{Zaključek}

Z uvedbo t.i. postopka whistleblow oziroma postopka o ugotavljanju in javljanju nezakonitosti, nepravilnosti in preprečevanju neracionalnega trošenja proračunskih sredstev, bi se varovanju delovanja javne uprave in načelu dobrega upravljanja laže približali. Evropska unija s sprejemom Kadrovskih predpisov, ki so stopili v veljavo s 1. majem 2004, podpira visoko kakovostno javno upravo, čim učinkovitejše upravljanje s človeškimi viri v evropski javni upravi,

28 Tudi pri nas ZJU ločuje javnega uslužbenca na uradnike in strokovno-tehnične javne uslužbence, vendar je pri ESČP zelo poudarjen funkcionalni kriterij, torej v tolikšni meri lahko posameznik dejansko vpliva na izvrševanje javne oblasti ne glede na organ ali mesto, kjer je zaposlen. 


\section{Mirko Pečarič \\ Razkrivanje nepravilnosti v Evropski uniji in Republiki Slovenji}

pravico javnih uslužbencev do svobode izražanja s pravnim okvirom in jamstvi za varstvo uradnikov, ki jasno definiranim osebam ali organom naznanijo možno nezakonito dejavnost ali obnašanje, ki pomeni hudo kršenje obveznosti uradnikov v službi EU. Kadrovski predpisi torej zajemajo novo miselnost zagotavljanja legitimnosti delovanja vseh institucij in organov $v$ očeh javnosti in državljanov EU, medtem ko se nekatere države članice na nacionalni ravni tem idejam približujejo (Irska, počasi tudi Francija) so jih druge že prehitele (Nizozemska, Velika Britanija), drugim pa so še tuje. Na to, da bi lahko dobroverni uradnik brez strahu in lastne škode naznanjal nezakonita ali nepravilna ravnanja $\checkmark$ javni upravi, vodstvo še vedno gleda kot na zlonamerno izdajanje napak in privilegijev vodstva. In prav ta uradnik je najboljši vir vseh informacij in podatkov za razkrivanje vseh nezakonitih, neekonomičnih in nesorazmernih ravnanj javne uprave. Tako spoznanje o odgovornem ravnanju magistratov je izšlo že iz antične Grčije, romalo je $\vee$ srednjeveško Anglijo, se preselilo $\vee$ ZDA, sedaj pa se kažejo orisi plodnih tal v EU in nekaterih državah (npr. Irska); medtem ko bo treba $\vee$ drugih državah članicah na učinkovito izvrševanje te pravice še počakati. Kljub obstoju organov odkrivanja in pregona, inšpekcijskih služb ter finančnih nadzorstvenih mehanizmov se je izkazalo, da le-ti niso dovolj hitri v primerih samega nastajanja in izvrševanja nepravilnosti; $\vee$ veliko večji meri gre za kurativno dejavnost, ki ima hujše posledice.

Pravni red vsake države je usodno vpet $v$ njen vrednostni sistem. Ljudje, ki so zato poklicani $v$ okviru javne uprave, bi si morali prizadevati za uveljavljanje vrednot. Svobodno izražanje mnenj o nepravilnem ravnanju $v$ najširšem pomenu, brez škode za vir informacij, sledi vrednotama pravičnosti in resnice. Če je edina legitimna moč moč argumenta (Jürgen Habermas), prisluhnimo torej tistim, ki o predmetni zadevi vedo največ. In $\vee$ okviru javne uprave so to vsekakor - javni uslužbenci. Med uradno dogmo in prepričanjem ljudi mora biti vedno prostor za razmislek, za reinterpretacijo pravil in pravic, za ohranitev vitalnosti, humanosti in združevanja z zamišljenimi idejami družbenega življenja. Zbujanje strahu in nevarnosti je ukrep iz preteklosti, ki se ponekod še vedno ohranja. Ne moremo dopustiti, da bi se pred tem nujnim ukrepom za zavarovanje javnega interesa in tistega, ki ga varuje, zgodilo karkoli nezaželenega za katerokoli človeško usodo ali državo kot celoto.

Dr. Mirko Pečarič je leta 1995 diplomiral na Visoki šoli za notranje zadeve, dve leti kasneje pa še na Pravni fakulteti v Ljubljani. Na Pravni fakulteti v Ljubljani je med magistrskim študijem opravil pravniški državni izpit, leta 2006 pa je uspešno zaključil doktorski študij s področja javne uprave. Zaposlen je kot svetovalec Državnega sveta Republike Slovenije, kjer opravlja dela in naloge sekretarja Komisije za politični sistem. 


\section{Mirko Pečarič \\ Razkrivanje nepravilnosti v Evropski uniji in Republiki Sloveniji}

\section{Literatura}

- Garner, B.A. (2004): Black's Law Dictionary, 8th ed., St. Paul: Thomson West.

- Dresang, D.L. (1999): Public Personel Management and Public Policy. London: Longman.

- Vincent, D. (1999): The Culture of Secrecy: Britain 1832-1998. Oxford: University Press.

- Virant, G. (2004): Komentar zakonov s področja uprave. Inštitut za javno upravo pri Pravni fakulteti. Ljubljana.

Pravni viri:

- Zakon o ratifikaciji Civilnopravne konvencije o korupciji, Uradni list, MP, št. $8 / 2003$

- Zakon o javnih uslužbencih (Ur.I. RS, št. 56/2002 in nasl.)

- Kodeks ravnanja javnih uslužbencev (Ur.I. RS, št. 8/2001)

- Kodeks primernega obnašanja za javne uslužbence. Dostopno na: http://europa.eu/index_sl.htm

- Listina o temeljnih pravicah evropske unije. Dostopno na: http://europa.eu/index_sl.htm

- Uredba Sveta (ES, Euratom) št. 723/2004. Dostopno na: http://europa.eu/index_sl.htm

- Kadrovski predpisi za uradnike Evropskih skupnosti in Pogoji za zaposlitev drugih uslužbencev Evropskih skupnosti, določeni v Uredbi (EGS, Euratom, ESPJ) št. 259/68, nazadnje spremenjeni z Uredbo (ES, Euratom) št. 2182/2003. Dostopno na: http://europa.eu/index_sl.htm

- Uredba (ES) št. 1073/1999 Evropskega parlamenta in sveta o preiskavah, ki jih izvaja Evropski urad za boj proti goljufijam. Dostopno na: http://europa.eu/index_sl.htm

- Sarbanes-Oxley Act. Dostopno na: www.findlaw.com

- Opinion 1/2006 on the application of EU data protection rules to internal whistleblowing schemes in the fields of accounting, internal accounting controls, auditing matters, fight against bribery, banking and financial crime.

- Dostopno na:

http://ec.europa.eu/justice_home/fsj/privacy/docs/wpdocs/2006/wp117_en.pdf. 


\section{Mirko Pečarič \\ Razkrivanje nepravilnosti v Evropski \\ uniji in Republiki Slovenji}

Drugi viri:

- $\quad$ Albreht M. (2004): Javni uslužbenci brez učinkovite zaščite in Vlada si zatiska oči in ušesa. V: Dnevnik in Delo, 19. 4. 2004.

- $\quad$ Bender D. (2006): Whistleblower Debate. Dostopno na: http://www.whitecase.com

- $\quad$ Poročilo o delu OLAF za obdobje od 1.7.2002 do 30.6.2003. Dostopno na: http://europa.eu.int/comm/anti_fraud/reports/olaf/2002-2003/en.pdf

- Draft OECD toolkit for managing conflict of interest in the public sector. Dostopno na: http://www.oecd.org/dataoecd/3/45/31571360.pdf

- http://euprava.gov.si/e-uprava/

- $\quad$ http://www.tiscali.co.uk/reference/encyclopaedia/hutchinson/m0026975.html

- $\quad$ http://www.globalcompliance.com/pdf/cnil-whistleblowingschemes.pdf

- $\quad$ http://www.oecd.org/dataoecd/3/45/31571360.pdf

- $\quad h t t p: / / w w w . c n i l . f r$

- www.euro-ombudsman.eu.int/home/sl/default.htm

- www.workrights.org/issue-whistle/wb-legislative-brief.html

- $\quad$ http://www.pcaw.co.uk/policy_pub/pida.html

- www.falseclaimsact.com/history.html.

- $\quad$ http://www.quitam.com 


\section{SUMMARY}

\section{WHISTLEBLOWING IN EUROPEAN UNION AND IN REPUBLIC OF SLOVENIA}

For long the field of executive power was in the shadow of legislative and juridical power, because of the conviction, that the executive power is only a tool of the legislative power, only performing its orders and never operating with political bias. Because of quick technological development and other change in all the fields of society it turned out that efficiency of political decisions is dependent from the executive power. With increase of impact of the executive power, the legislative power has realized its increasing bureaucratic tendency and therefore has been introducing more control upon the executive power. Beside political juridical control of public service is growing. There is no longer question if the political institutions can control the bureaucracy; indeed there is new one: can they control it without harming it.

Lately importance of the executive power has been clearly pronounced in constituting and activities of European Union (EU), which as counterpoise to the Reform treaty try to emphasise the classical democratic principle and the division of power. With special regulations European union introduced whistleblow procedures, known in majority of states in United States of America, Great Britain, Australia, Canada, New Zealand and South Africa. With introduction of whistleblowing or procedure of disclosing illegality, irregularity and irrational spending of budgetary means, it is much easier to pursue the principle of good governance. In spite of the existing inspection and financial control mechanisms it has turned out that they are not sufficient and fast enough in cases of occurring of irregularities; in most cases they perform a kind of curative activity.

The principle of good governance might be interpreted as the basic principle of public service considering the principles of legality, legal certainty, anticipation, political neutrality, orientation towards consumer, transparency, quality, efficiency and effectiveness and it must include not only protection of human rights, but also expedience, efficiency, effectiveness, proportionality, rationality and responsiveness of public service. All these high objectives cannot be ensured by the state, not even by its 
Mirko Pečarič

Razkrivanje nepravilnosti v Evropski

uniji in Republiki Slovenji

citizens, but by the people whose profession is realising those goals namely the public servants.

With regulation of council no.723/2004 from 22. March 2004, EU changed The Staff Regulations of officials and the conditions of employment of other servants of EU. Any official who, in the course of or in connection with the performance of his duties, becomes aware of facts which give rise to a presumption of the existence of possible illegal activity, including fraud or corruption, detrimental to the interests of EU, or of conduct relating to the discharge of professional duties which may constitute a serious failure to comply with the obligations of officials of EU, shall without delay inform either his immediate superior or his DirectorGeneral or, if he considers it useful, the Secretary-General, or the persons in equivalent positions, or the European Anti-Fraud Office (OLAF) directly. The Staff Regulations of officials and OLAF (beside Ombudsman) roughly follow the content of American whistleblow procedure, also known by Great Britain as an EU member.

From the provisions of Slovenian law on the public servants it is obvious that rights and obligations from labour relation contain only rights and obligations from labour relation in very narrow sense, namely only executing of assignments which are connected with labour legislation and collective agreements. Nothing has been said about the rights of public servants to participate in constructing of laws and executive regulations. Proper and only realisable principles of legality, professionalism, responsibility for results, good governance and protection of professional interest could be possible only in conditions of right to participate of public servants instead of threat of disciplinary procedure in case of violation. The author is advocating a proceeding, enabling servants with bona fide to advise assessment of orders, without being victims of consequences. A temporary or permanent agency might be created, from senior officers in the proceeding. Their opinion would not be obligatory; if the servant would not be satisfied with that opinion, he could go to court. A possible solution could include negotiations, discussions between servants, superior and other management. In unsuccessful case there would be a quasi mediation managed by a commission of experts. Introduction of commissions, councils would represent a kind of mediation, which could keep servants away from later court judgement and would avoid unnecessary damage because of prompt decision. In such a way a not binding, expert practice would be introduced, assessing the regularity of decisions in later 


\section{Mirko Pečarič \\ Razkrivanje nepravilnosti v Evropski uniji in Republiki Sloveniji}

cases of eventual court actions upon the right and obligations of their clients. At the same time, it would promote important feelings in public servants that they are contributing to the practice of execution of laws and regulations.

EU with reception of Staff Regulations constitutes the directions for public service quality, efficient management of public resources in European public service and the rights of public servants to freedom of expression. There are a legal frame and guarantees for protection of servants, announcing to clearly defined persons or agencies a possible illegal activity which signifies a considerable breach of obligation of servants in the service of community. Staff regulations represent a new thinking in assurance of legitimacy in activity of all institutions in public and citizens opinion, nevertheless some states on national level slowly approach that kind of thinking. Initiation of private detectives in law of public servants for detecting a misuse of travel expenses or sick leave, bill on detective activity also for use of detectives in investigation of all disciplinary violations, abolition of anticorruption commission as independent agency and "unproblematic" conflicts of interest are examples, which allow reduction of expertise, honour, freedom of expression of public servants and reputation of state agencies. Considering that all people have good imagination, people with better possibility of spending budgetary means and "public" authority can better use their imagination. In such circumstances it is illusory to expect that this imagination would not be practised. Legal order of every state is fatally interwoven in the value system. The people, employed in the public service, should endeavour the practice the values. Free expression of opinion on irregular behaviour, without any harm for the source of information, pursues values of justice and truth. If the only legitimate power is the power of the argument, it is advisable to hear those that know the most about the matter. In public service those people are undoubtedly - public servants.

The article is emphasising the relations between law and public servants as humans, as servants of the state and servants of the people, not appointed because of defiance, but despite the obligation of loyalty they sometimes should defiance to improper rules or practice. In the paper we derive from relationship between freedom and safety, from urgency of dialogue and necessity of disclosing irregularities, which will be performed only at a certain level of culture of nation. Accordingly the paper shows that the perception of officials about change in the environment, in 
Mirko Pečarič

Razkrivanje nepravilnosti v Evropski

uniji in Republiki Slovenji

which rules operate, and accommodation of the rules to the objectives and meaning of the law, are urgent for rule's survival. With obligatory consideration of constitutional and legal principles individual rules can be changed, in mutual acknowledging the diversity and cooperation among people for better employment of still unused human potential in state agencies. 